\title{
How does new business formation affect regional development? Introduction to the special issue
}

\author{
Michael Fritsch
}

Received: 15 April 2007/Accepted: 19 April 2007/Published online: 12 July 2007

(C) Springer Science+Business Media B.V. 2007

\begin{abstract}
This paper gives an overview of the empirical research on the effects of new business formation on regional development and introduces the contributions to this special issue. The effects of new businesses on regional development emerge over a longer time-period of up to ten years. A main focus of the contributions to this special issue is on the distribution of these effects over time and on the magnitude of the overall effect. While the basic pattern found for the different countries and regions is quite similar, the magnitude of the overall effect can be different and may even be negative. There are strong indications, that the type of entrants plays an important role in this respect.
\end{abstract}

Keywords Entrepreneurship - New business formation · Regional development · International comparison

Michael Fritsch $(\bowtie)$

Faculty of Economics and Business Administration, Chair of Business Dynamics, Innovation, and Economic Change, Friedrich-Schiller-University Jena, Carl-ZeissStr. 3, 07743 Jena, Germany

e-mail: m.fritsch@uni-jena.de

Michael Fritsch

German Institute for Economic Research (DIW), Berlin, Germany

Michael Fritsch

Max Planck Institute of Economics, Jena, Germany
JEL Classifications $\quad \mathrm{L} 26 \cdot \mathrm{M} 13 \cdot \mathrm{O} 1 \cdot \mathrm{O} 18 \cdot \mathrm{R} 11$

\section{Aims and scope}

It seems rather plausible to expect that new business formation stimulates growth. As a consequence, many policy makers as well as scholars believe that stimulating new business formation is a promising way for achieving economic growth. This belief is also a main motivation of most of the research in this field. The empirical evidence concerning the effects of new business formation on economic development is, however, far from being entirely clear. Until recently, only very few empirical studies could provide persuasive evidence of a positive statistical relationship between new business formation and growth while many other studies could not find such an effect (see the overview by Carree and Thurik 2003). We still do not have sufficient knowledge about the ways in which new business formation shapes economic development and what time period it takes until the effects become visible in empirical data.

The contributions to this special issue all provide evidence on the effect of new business formation on economic development in the short, medium and long run. They are based on a workshop that took place at the Max Planck Institute of Economics in Jena, Germany in July 2005. This introductory chapter discusses the state of research on the effects of new business formation on development. What are the 
relevant hypotheses? What empirical evidence do we have? What are the main research questions? Section 2 will first provide a conceptual framework for investigating the effects of new business formation on growth. Section 3 gives an overview of the different approaches to assess the impact of new businesses on development and reviews the available empirical evidence. An overview of the main results of the contributions collected in this special issue follows in Section 4. Section 5 provides conclusions for policy as well as for further research.

\section{Possible effects of new firm formation on economic development}

\subsection{Review of the effects}

The main starting point of the discussion and empirical research on the effects of new business formation on economic development was a study conducted by David Birch (1979) titled "The Job Generation Process," which circulated as a mimeographed research report (see also Birch 1981, 1987). Birch asserted that small and, particularly, new businesses are the main job generator in the USeconomy. This study found a tremendous echo in the political as well as in the academic sphere. Responses ranged from enthusiastic praise for a new solution to employment problems to pronounced skepticism (see for example Storey 1994, for a review on initial reactions to the Birch study). Most importantly, however, it stimulated numerous follow-up analyses for the USA and for many other countries. One main innovation of the Birch study was that it analyzed longitudinal micro-level data that covered nearly the entire US economy. Unfortunately, reliable information on new business formation and longitudinal micro-level data, which would have allowed the employment of firms and establishments ${ }^{1}$ to be tracked over the years, was hardly available at the

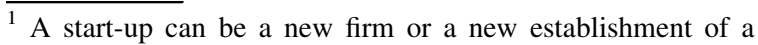
multi-plant enterprise. The term "new business" is used here as an overall category that encompasses the set up of a new headquarters as well as the creation of a new subsidiary establishment.
}

time when this discussion began. ${ }^{2}$ Therefore, considerable efforts had to be directed in order to make the existing data sources accessible for research and for the creation of new ones. Also in this respect, the Birch study had an enormous impact.

For understanding and judging the results of the diverse analyses that have been carried out since the beginning of the debate, a systematic review of the different types of effects of new business formation on economic development is helpful. New firms represent an entry of new capacities into the market and are, therefore, an essential element of the market process. The evolution of the newcomers, e.g., given by the number of their employees or by their market share, may be labeled as the direct effect of new capacities. This is, however, only a part of the contribution that the new businesses make to economic development. Due to competition and market selection, only a fraction of the start-ups will survive for a longer period of time (Boeri and Cramer 1992; Fritsch and Weyh 2006), and those which do succeed in establishing themselves in the market may displace incumbents. Therefore, two types of exiting capacities may result from the entry of new businesses. Firstly, a considerable part of the new businesses fail to be sufficiently competitive and, thus, have to leave the market after some time. And secondly, the crowding-out of incumbents by their new competitors leads to declining market shares or market exit. These effects are rather indirect in nature. Given that market selection works according to a survival of the fittest scenario, firms with relatively high productivity will remain in the market while those with a low productivity have to reduce their output or exit. ${ }^{3} \mathrm{At}$ a constant output level, this market selection process should lead to a decline in employment, not to new jobs, because fewer resources are needed in order to produce the given amount of goods and services at a higher productivity level. Hence, although starting a new business means creating additional capacities that require personnel to operate them, the effect of

\footnotetext{
${ }^{2}$ Birch (1979) used micro-data from the Dun \& Breadstreet credit rating agency for the USA in the 1969-1976 period.

${ }^{3}$ Crowding-out effects may occur in the output market because the entrants gain market share as well as in the input market due to the additional demand of the new businesses for resources can that lead to scarcity of inputs and increasing factor prices.
} 
new business formation on the number of jobs in the economy does not necessarily need to be positive but could just as well be negative.

However, a well-functioning market process is in no way a zero-sum game in which the gains of one actor are necessarily completely at the expense of the other actors. There are several ways in which competition by entry of new businesses can stimulate employment growth on the supply-side of the market. The main supply-side effects of entry could be (cf. Fig. 1):

- Securing efficiency and stimulating productivity increase by contesting established market positions. Not only the actual entry but also the very possibility of an entry forces the incumbents to perform more efficiently (Baumol et al. 1988).

- Acceleration of structural change. It can frequently be observed that structural change is mainly accomplished by a turnover of the respective economic units, i.e., by entries of new firms joined by exits of old-established incumbents. In this case, the incumbents do not undergo necessary internal changes, but rather are substituted by newcomers. ${ }^{4}$ This type of process has been emphasized by J.A. Schumpeter's (1911/ 1934, 1942) concept of ,creative destruction” and by Alfred Marshall's (1920) analogy of a forest in which the old trees must fall in order to make way to the new ones.

- Amplified innovation, particularly the creation of new markets. There are many examples of radical innovations that have been introduced by new firms (Acs and Audretsch 1990; Audretsch 1995; Baumol 2004). One major reason for this pronounced role of new firms in introducing radical innovation could be that incumbent suppliers are more interested in exploiting the profit possibilities of their given product program versus searching for new opportunities, particularly if the new products may contest their established ones (Geroski 1995, 431; Klepper and Sleeper

\footnotetext{
${ }^{4}$ Such a process could, for example, be observed in the transformation of former socialist economies of Central and Eastern Europe, where new firms - the bottom-up component had a considerably stronger impact on structural change, cf. Brezinski and Fritsch (1996) and the contributions in Pfirrmann and Walter (2002).
}

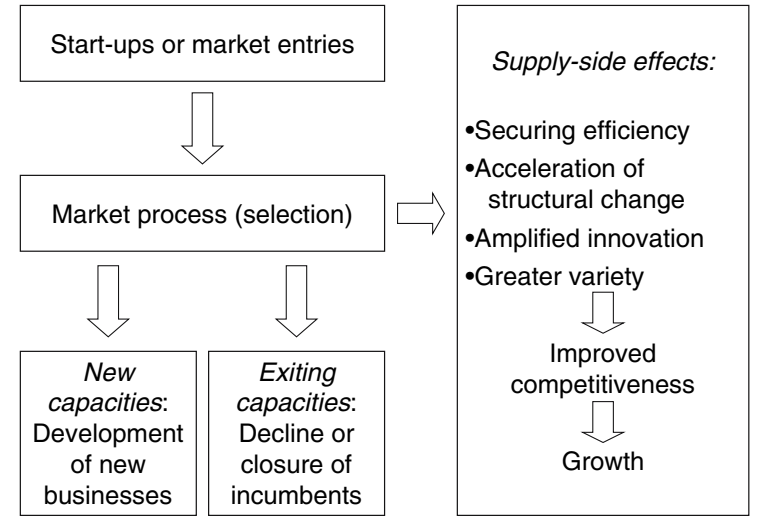

Fig. 1 New business formation and the market process

2005). Due to such reluctance that this sort of incumbent firms have towards new ideas, to set up one's own business may appear to be the only or the most promising possibility for inventors to commercialize their knowledge (Audretsch 1995; Klepper and Sleeper 2005).

- Greater variety of products and problem solutions. If the product program of a newcomer differs from those of the incumbents, or if an entrant introduces significant process innovation, this leads to a greater availability of goods and problem solving methods. Such an increased variety implies a higher probability of finding a supply with a better match for customer preferences. Increased variety due to new supplies may stimulate an intensified division of labor as well as follow-up innovation and can, therefore, generate significant impulses for economic development.

These effects are rather indirect in character and lead to improvements on the supply-side of the market. They are not necessarily limited to the industry to which the start-up belongs, but rather may also occur in completely different industries that use the improved supply as an input. They also do not have to be limited to the region in which the entry occurs but can also emerge in other regions (see Section 2.2). The indirect supply-side effects are the drivers of competitiveness of the respective industries that may induce employment growth and increasing welfare. They are the reason why one should expect positive employment effects of new business formation. 
It is important to note that the emergence of the supply-side effects of new business formation does not necessarily require the newcomers to be successful and to survive. As long as entry induces improvements on the side of the incumbents, it will generate positive supply-side effects, even if most of the new businesses fail and have to exit the market soon after entry. Therefore, even the failed start-ups may make a significant contribution to the improvement of supply and competitiveness. ${ }^{5}$ Failure of new businesses may, however, not be completely irrelevant because a high probability of failure could discourage potential market entry.

This review of the different impacts of new business formation on market processes makes very clear that the evolution of the new businesses represents only a portion of their total effect on development. The most important influence that the start-ups have on growth and employment occurs rather indirectly on the supplyside. As far as the market process is working according to a survival of the fittest scenario, the direct employment effects, i.e., the growth of new businesses, as well as the displacement of incumbents, should sum up to a decline in employment. Under a properly functioning market regime, growth from new business formation can only be expected from improvements on the supply-side. If, however, the process of market selection does not work as it should and allows the survival of relatively unproductive competitors, this would then weaken the competitiveness of the economy and, thus, cause the supply-side effects to become negative.

It is plausible to assume that the challenge that a new business poses upon its competitors on the output market critically depends on its quality. Quality can mean multiple issues here such as the entrepreneurial skills of the founder(s), the knowledge base and other resources of the new business as well as its innovativeness. Therefore, the innovative entry of businesses that are led by well-prepared entrepreneurs who have the necessary knowledge and other resources available, can be expected to have a stronger effect and, particularly, lead to larger supply-side improvements than non-innovative new businesses which are run by persons without appropriate skills and are not

\footnotetext{
5 Thus, even in a "revolving door" regime in which the vast majority of the entries soon have to exit the market (Audretsch 1995), the start-ups may have an important effect to the extent that they are a challenge for the incumbents.
}

successful at sufficiently accessing the relevant factors of production. It could also be expected that the supply-side effects will be relatively large in markets which are characterized by a high intensity of competition because of greater pressure for improvements. Moreover, supply-side effects may be larger in global product markets as compared to local services due to greater numbers of direct competitors that are affected by the challenges of an entrant.

\subsection{Regional effects}

Thus far, the effects of new business formation have been discussed with the implicit assumption that the geographical unit of observation encompasses the entire input and output market, which is relevant for the start-ups. If the effects in a certain region are analyzed and if this region covers only a part of the relevant markets, considerable differences can be found in the effects between the regions for a number of reasons:

- First, start-ups in different regions can be of dissimilar quality and, therefore, more or less successful with regard to survival and employment growth; thus, the direct employment effects can vary considerably.

- Second, the crowding-out effect of a successful entry may not occur in the same region in which a start-up takes place but in other regions.

- Third, the supply-side effects can also occur in other regions, resulting from the competitors located in these regions which introduce improvements in their supply.

This suggests a number of hypotheses concerning regional differences, such as the following:

- Regions with a large share of high quality startups may experience stronger direct employment effects than regions in which only very few of the new businesses are of such a high quality.

- Success of start-ups and direct employment effects should also be higher in regions where relevant resources are abundant and competition for these resources is not very intense. Because the incumbents also benefit from such a favorable environment, displacement effects should be relatively low and supply-side effects may be relatively pronounced. 
- Regions in which most of the businesses are characterized by a relatively low productivity level can be expected to experience a much more pronounced decline in employment due to displacement effects, in comparison to regions where a high share of the suppliers is in the high productivity range. Also, the supply-side effects in low productivity regions should be smaller if those challenged incumbents, which are located in other regions, operate in the high-productivity range.

- The magnitude of the supply-side effects in a region may depend on the innovativeness of the regional suppliers as well as on the quality of the regional innovation system in which they are embedded. Among the factors that can be expected to shape the efficiency of the regional innovation system are the qualification of the regional workforce, the presence of academic research institutions, the innovativeness of other firms in the region as well as the availability of innovation related business services (Fritsch and Slavtchev 2007).

- The magnitude of the effects may, particularly, depend on the size of the respective industry in the region. If, for example, a successful start-up is the only supplier of the industry located in the region, output-induced crowding-out effects will not occur and supply-side effects may be relatively small.

Obviously, the effects of new business formation cannot be expected to be identical in all regions, but rather there should be considerable differences. The employment effects of new business formation will probably be rather positive in high productivity regions with high-quality entries, abundant resources and a well-functioning innovation system. They will be much smaller or may even be negative in low productivity regions with low-quality entries, scarcity of relevant resources and an inefficient innovation system.

\section{Review of the empirical evidence}

\subsection{Different approaches to analyze the effect of new business formation on economic development empirically}

The discussion about the effects of new business formation on economic development has focused on employment creation for a long time. One reason for this concentration on employment is probably the particular concern of policy for job generation and for the prevention of unemployment. Another reason may be the greater availability of information on employment as compared to other performance indicators, especially at the micro-level of firms ${ }^{6}$ as well as for regions and industries. Many of these studies followed the approach taken by Birch (1979) and analyzed employment development of cohorts of businesses, particularly of newly founded businesses. Although this type of analysis may be well suited to detect the direct employment effects of start-ups, it is not possible to examine any indirect effects with such an approach. Because new businesses by definition create new jobs, this direct employment effect cannot be negative. In order to also account for the indirect effects of new business formation on development, the relationship between new business formation activity and some aggregate performance measure such as the change of employment, the change of gross domestic product or the change of productivity in the respective country, region or industry, has to be analyzed.

For a meaningful comparison of regions or industries of different size or different economic potential, the number of start-ups has to be related to a measure of this economic potential, i.e., a start-up rate should be used. Most commonly, the number of employees is chosen as the denominator of the start-up rates what Audretsch and Fritsch (1994) labeled the 'labor market' approach. This kind of start-up rate is based on the notion that each member of the workforce is faced with the decision to work as a dependent employee in someone else's business or to start his or her own firm. The entry rate according to the labor market approach may be regarded as the propensity

\footnotetext{
${ }^{6}$ Another output measure for which information is frequently available at the micro-level of firms is turnover. Compared to employment, turnover as an output-indicator has at least two disadvantages. First, if firms have different shares of value added, the development of turnovers may not adequately reflect the development of their level of economic activity. Second, information on turnover is hardly available on an establishment level for those economic units that belong to a multiestablishment firm. In these cases, turnovers cannot be correctly assigned to the regions of the establishments.
} 
of a member of the regional workforce to start an own business. $^{7}$

To analyze the relationship between start-up rates and the development of employment or turnover at the level of industries leads to serious difficulties in the interpretation of the results. If industries follow a life-cycle, then the number of entries and the start-up rate will be relatively high in the early stages of the life-cycle when the industry is growing, and it will be relatively low in latter stages in which the industry declines (Klepper 1996). Can the resulting positive correlation between the start-up rate and development of the industry in subsequent periods be regarded as an effect of entry on growth? Probably not-and, indeed, entirely different results are found if, for example, the relationship between the level of startups and subsequent employment change is analyzed on the level of regions and on the level of industries (see Fritsch 1996). This clearly demonstrates that geographical units of observation are much better suited for such an analysis than industries.

Nearly all of the available empirical studies that have analyzed the impact of new business formation on the development of regions or countries use correlations or regressions for assessing the relationship between an indicator of the level of new business formation activity (e.g., a start-up rate) and a measure of economic development that is based on employment or on GDP (e.g., Reynolds 1994, 1999; Audretsch and Fritsch 1996, 2002; Fritsch 1996, 1997; Acs and Armington 2002; van Stel and Storey 2004; Fritsch and Mueller 2004). ${ }^{8}$ Some studies have included an indicator for entrepreneurship into a production function that contains information on the contribution of other inputs to growth (Audretsch and Keilbach 2004; Audretsch et al. 2006; Wong et al. 2005). In this type of approach, entrepreneurship is regarded as a production factor that introduces resources such as initiative, opportunity recognition

\footnotetext{
${ }^{7}$ Because start-ups are usually located close to the residence of the founder(s) (Gudgin 1978; Mueller and Morgan 1962; Cooper and Dunkelberg 1987), the regional workforce can be regarded as an appropriate measure of the number of potential entrepreneurs.

${ }^{8}$ Bosma et al. (2006) analyzed the effect of a turbulence rate (number of entries plus number of exits divided by the number of existing businesses) on the change of total factor productivity of regions.
}

as well as the willingness and the ability to take risk into the model.

The advantage of analyzing the contribution of entrepreneurship within the framework of a production function is that this approach is more comprehensive than the regression of start-up rates on development because it systematically accounts for other determinants of growth, and it has a foundation in production theory. However, entrepreneurs do not accomplish success and growth by spirit and initiative alone, but rather they must hire labor and make capital investments. Hence, in a production function framework that includes the inputs of labor and capital parts of this impact of entrepreneurship on development may be attributed to labor and capital and not to the entrepreneur who made the respective decisions. Therefore, the effect of entrepreneurship may well be underestimated in this sort of analysis. However, those empirical studies, which more or less solely relate the start-up rate to growth, are in danger of overestimating the effect of entrepreneurship due to the neglect of other factors. A severe bottleneck of applying the production function approach is that it is rather demanding with regard to necessary data. Particularly, data on the capital stock must generally be regarded as figures of questionable reliability and are, in many countries, hardly available on a regional basis.

\subsection{Empirical evidence on the effects of new business formation on economic development}

The first systematic analysis of the relationship between the level of new business formation and regional employment change has been conducted by Reynolds $(1994,1999)$ for the USA. Reynolds found a pronounced positive effect. However, conducting the analysis for different time periods revealed considerable variation. A positive relationship between the regional level of start-ups and subsequent growth was confirmed by Ashcroft and Love (1996) for the UK, by Acs and Armington (2002) for the USA, by Brixy (1999) for East Germany as well as by Braunerjhelm and Borgman (2004) for Sweden. But a number of other studies could not identify such a positive relationship between the level of start-ups and regional employment growth (Audretsch and Fritsch 1996; Fritsch 1996, 1997; EIM 1994). In an international cross-section analysis for 36 countries 
participating in the GEM project, Van Stel et al. (2005) found some confirmation for a positive effect of "total entrepreneurial activity" (TEA) ${ }^{9}$ on GDP growth in highly developed countries but not for the poorer countries of the sample. Audretsch and Keilbach (2004) included the start-up rate into a Cobb-Douglas production function and identified a positive effect on the level of GDP as well as on labor productivity in West German regions. In a study based on GEM data for 37 countries Wong, Ho and Autio (2005) divided the indicator of total entrepreneurial activity into several groups. A significantly positive impact on GDP growth was only found for "high growth potential" TEA ${ }^{10}$ but not for overall TEA, necessity TEA and opportunity TEA. ${ }^{11}$

One reason for the partly mixed results of the studies analyzing the impact of new business formation on employment change could be that the entry and turnover of establishments (firms) may lead to a productivity increase (see Baldwin 1995; Disney, Haskel and Heden 2003; Foster et al. 2001; OECD 2003), which compensates for the employment effect. Another reason may be that not all of the effects of new business formation on employment emerge immediately at the time when the newcomers enter the market. Due to data restrictions, the analyses mentioned above did not include any or only rather short time-lags between the occurrence of the startups and the respective effect on output and may, therefore, have assessed the effects on regional development only rather incompletely. In an analysis for West German regions, Audretsch and Fritsch (2002) did, indeed, find evidence for positive longterm effects of new business formation. In this study,

\footnotetext{
${ }^{9}$ Total entrepreneurial activity is the percentage of the adult population between 18-64 years old that is either actively involved in starting a new venture or is the owner/manger of a business that is less than 42 months old (Reynolds et al. 2005).

${ }^{10}$ A venture was classified as having a "high growth potential" if it fulfilled our criteria: (1) the venture plans to employ at least 20 employees in 5 years; (2) the venture indicates at least some market creation impact; (3) at least $15 \%$ of the customers of the venture normally live abroad; and (4) the technologies employed by the venture had not been widely available more than a year ago" (Wong, Ho and Autio 2005, 345).

${ }^{11}$ Necessity entrepreneurship is understood as a start-up that occurs because of missing alternatives (e.g., out of unemployment). A new business that is set up to pursue an opportunity is classified as an "opportunity" entrepreneurship. See Reynolds et al. (2005) for details.
}

new business formation activity in the early 1980s could not explain regional employment change in the rest of the decade but provided an explanation of employment change in the 1990s.

Van Stel and Storey (2004) analyzed the relevance of such time-lags more systematically and estimated a time-lag structure of the effects of new business formation on regional employment growth with data for Great Britain. They confirmed that there are considerable time-lags between new business formation and its effect on regional development, which they found to be positive. According to their results, the magnitude of the effects over time takes the form of an inverse ' $u$ ' with a peak for the start-up activity that occurred five years earlier. The impact then becomes weaker and no effect of new business formation on regional employment could be identified for start-ups rates with a time-lag of more than ten years. A severe problem in such an analysis of the lag-structure emerges from a high correlation between yearly start-up rates. Due to such high correlation the original estimates may not reflect the 'true' lag structure. In dealing with this problem, van Stel and Storey (2004) applied the Almon polynomial lag procedure. This procedure attempts to approximate the lag structure by a polynomial function (see Greene 2003, for a detailed description of this method). In this type of analysis, an assumption has to be made about the order of the polynomial to be used for estimating the lag structure.

\subsection{The 'wave' pattern}

Fritsch and Mueller (2004) applied the Almon polynomial lag procedure in an analysis of the effect of new business formation on regional development in West Germany. They found that a statistically significant effect of new business formation on employment is restricted to a period of about ten years. While van Stel and Storey (2004) had assumed a second-order polynomial for estimating the lag structure of new business formation rates, Fritsch and Mueller (2004) also applied higher order polynomials. With a third and higher order polynomial, they found a 'wave' pattern of the effects as shown in Fig. 2. This figure depicts the original regression coefficients that have been found without application of the Almon lag procedure as well as the coefficients that result from this procedure by assuming a third- 


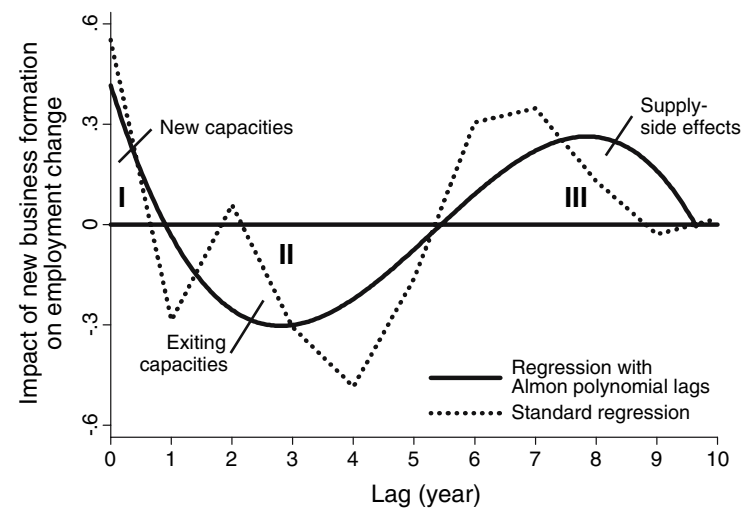

Fig. 2 The effects of new business formation on employment change over time in West Germany-regression coefficients for start-up rates and the results of the Almon lag procedure assuming a third-order polynomial

order polynomial. The resulting smoothened lag structure suggests that new business formation during the current year has a positive impact on employment change. For years $t-1$ to $t-5$, the effect is negative with a minimum in $\mathrm{t}-3$. For the entries in years $\mathrm{t}-6$ to $\mathrm{t}-9$, a positive relationship is found with a maximum between years $t-7$ and $t-8$. The magnitude of the effect then decreases and becomes slightly negative in the last year of the sample (t-10). The overall effect of new business formation on employment change can be measured by the sum of the regression coefficients for the start-up rates of the different years (Gujarati 2003, 658), which are depicted by the three areas in Fig. 2.

Fritsch and Mueller (2004) suggest the following interpretation of this wave-pattern that builds on the systematization of effects, which has been presented in Sect. 2. According to this interpretation, the positive employment impact for start-ups in the current year can be understood as the additional jobs that are created in the newly founded businesses at the time of inception. This direct employment effect is indicated in area I in Fig. 2. It is well known from a number of analyses that employment in entry cohorts tends to be stagnant or decline from the second or the third year onward (Boeri and Cramer 1992; Brixy and Grotz 2004; Fritsch and Weyh 2006). Therefore, new firm formation activity in year t-3 and more distant time periods should not lead to any significant direct employment effect. As soon as a new business is set up, it is subject to market selection and will, perhaps, gain market shares from incumbent suppliers. Thus, the negative impact of the start-ups in years $\mathrm{t}-1$ to $\mathrm{t}-5$ (area II in Fig. 2) are probably a result of exiting capacities, i.e., new businesses that fail to be competitive and from the displacement of incumbents. The positive impact of new business formation for years t-6 to t-10 on employment (area III in Fig. 2) is probably due to a dominance of indirect supply-side effects, i.e., increased competitiveness of the regional suppliers resulting from market selection. After about nine or ten years, the impact of new business formation on regional employment has then faded away.

When assuming a second-order polynomial for the Almon lag procedure, the resulting lag structure found by Fritsch and Mueller (2004) is 'u'-shaped (Fig. 3), not inversely ' $u$ '-shaped as was found in the analysis by van Stel and Storey (2004) for Great Britain. The interpretation of the ' $u$ '-shaped lag structure is quite similar to that for the wave pattern, which resulted from assuming a higher order polynomial. According to Frisch and Mueller (2004), the initial increase of employment can be regarded as the direct employment effect of new business formation (area I in Fig. 3). It is followed by a period in which the crowding-out effects prevail (area II), before the employment increasing supply-side effects finally start to dominate (area III). What is different between the two patterns is that these supply-side effects then become stronger and stronger without decreasing again in the more distant years.

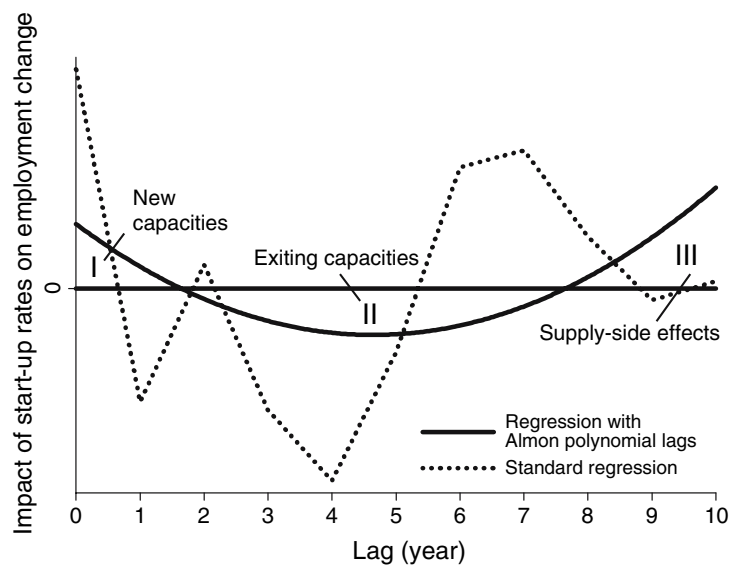

Fig. 3 The effects of new firm formation on employment change over time in West Germany-regression coefficients for start-up rates and the results of the Almon lag procedure assuming a second-order polynomial 
Such an increase is, however, highly implausible given the statistical insignificance of start-up rates during these periods. The increase in the curve for the latter periods is probably caused by the very nature of a second-order polynomial, which by definition possesses only one inflection point.

If the interpretation of the lag structure proposed by Fritsch and Mueller (2004) is correct, both patterns imply that the indirect employment effects as indicated in area I and II are more important than the direct effect, i.e., the initial employment created in the newly founded businesses (area I). This becomes particularly clear if the supply-side effects (area III) are compared to the net effect of new and exiting capacities, which is indicated in area I minus area II in Figs. 2 and 3. Moreover, since the analysis covers the direct effects completely but does not account for crowding-out effects as well as supplyside effects that occur in other regions, the relative importance of the indirect effects can be assumed to be even considerably higher.

\section{Overview of contributions in this issue}

The contributions to this special issue are all based on the workshop "The Effects of New Businesses on Economic Development in the Short, Medium and Long Run" that took place on July 11th and12th, 2005 at the Max Planck Institute of Economics in Jena, Germany. The aim of this workshop was to compare the empirical findings for different countries, particularly with regard to the wave-pattern that has been described in Section 3.4. Analyses have been conducted for Germany, Great Britain, the Netherlands, Portugal, Spain and the USA as well as for a sample of 21 OECD countries. Table 1 provides an overview of the data used and the main results of these studies. ${ }^{12}$

\footnotetext{
${ }^{12}$ Most of the studies use a sector-adjusted start-up rate in order to control for the effect that the composition of industries has on the number of start-ups. This would result in a bias of overestimating the level of entrepreneurship in regions with a high composition of industries where start-ups play an important role, and underestimating the role of new firm formation in regions with a high composition of industries where new-firm start-ups are relatively unimportant. To correct for the confounding effect of the regional composition of industries on the number of start-ups, a shift-share procedure is employed to obtain a sector-adjusted measure of start-up activity (see the Appendix of Audretsch and Fritsch 2002, for details).
}

Summarizing the main findings, one can say that there is rather strong supporting evidence for the wave pattern as identified by Fritsch and Mueller (2004) on the basis of data for West Germany. There are, however, some exceptions. The main exception in this respect is the study for Portugal (Baptista et al. 2007), which finds a ' $u$ '-shaped pattern of the lag structure. Van Stel and Suddle in their analysis for the Netherlands identify an inverse ' $u$ '-shaped pattern if the employment effects of the first two years are excluded. However, including these first two years resulted in the familiar s-shaped curve. Acs and Mueller in their study for US Metropolitan Statistical Areas (MSAs) identify a number of different lag structures when restricting the analysis to particular types of entry. However, when all entries are placed together, the curve is ' $s$ '-shaped.

Carree and Thurik in their contribution analyzed the effect of changes of the number of business owners, which indicates net-entry on growth in 21 OECD countries. They found a s-shaped pattern for employment change as well as for GDP change and for change of labor productivity as a dependent variable. However, the effects on GDP and labor productivity change are only statistically significant in the initial phase when the businesses are set up. The significantly positive effect of net-entry on labor productivity is rather remarkable given the results of many empirical analyses which showed that new businesses tend to enter with a below average productivity level, and it often takes a period of about 8-10 years until they attain that average level (Baldwin 1995; Bartelsman and Doms 2000; Carree and Thurik 1999; Farinas and Ruano 2005; Verhoeven 2004). If an excess of the number of entries over the number of exits does not result in a productivity decline of the economy, this indicates that—given the below-average productivity of the start-ups in the first years-entry stimulates improvements in the incumbent firms!

Obviously, there are important differences according to the type of entry and the characteristics of the region. The study for US-MSAs by Acs and Mueller identified a s-shaped lag structure according to the wave-hypothesis if all start-ups were included in the analysis. For start-ups of large firms with 500 or more employments ('elephants'), most of them probably branch plants, the curve for the lag structure was ' $u$ 'shaped. For start-ups of small firms with less than 20 


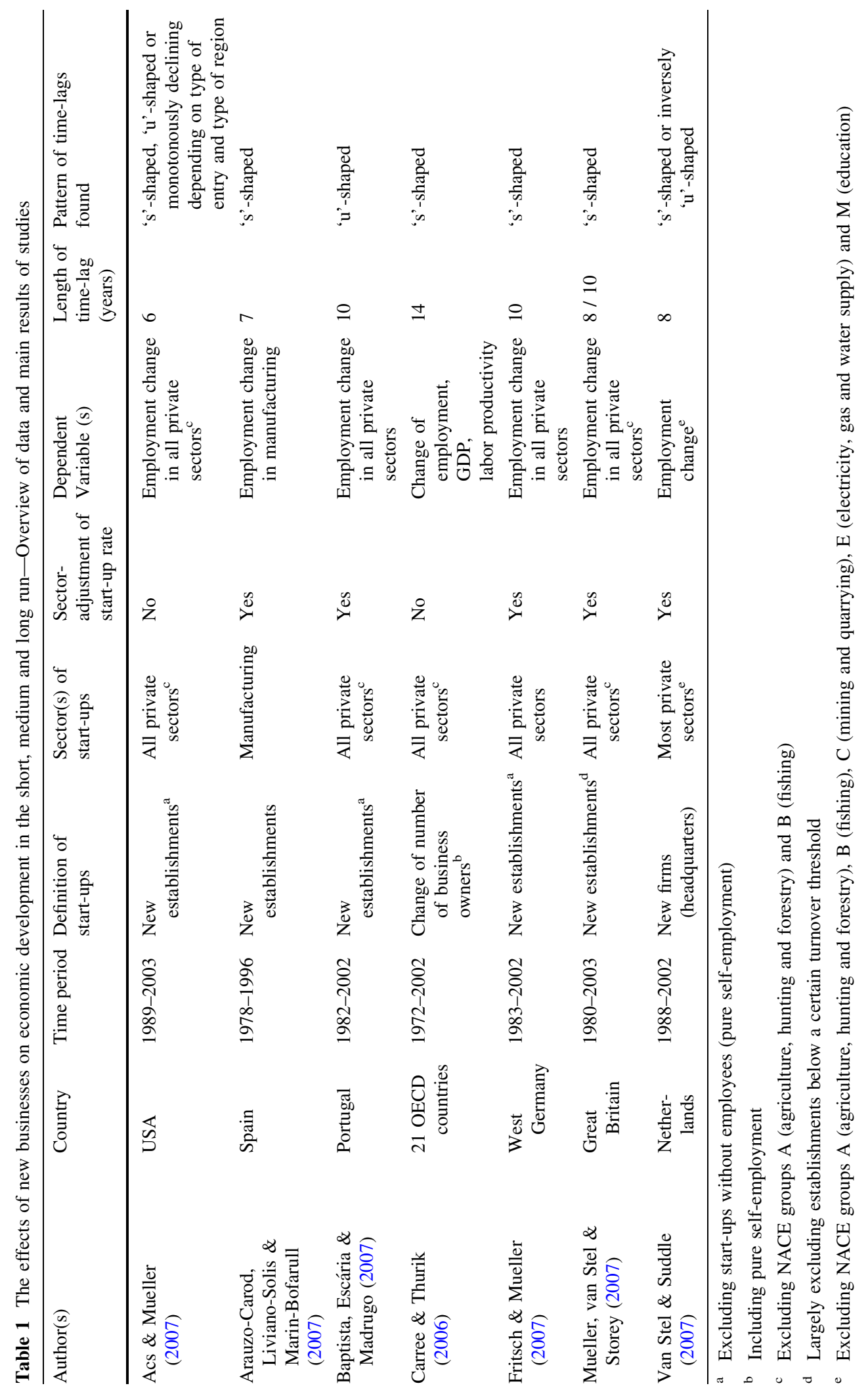


employees ('mice'), presumably most of them singleestablishment companies, the impact is always positive but with monotonously decreasing strength. Van Stel and Suddle investigated the effect of startups of different industrial sectors on overall employment change. They found that the effect of new businesses affiliated to the manufacturing sector is more than three times higher than that of start-ups in construction, transport \& communication and in service industries. The lowest impact was found for new businesses in the trade sector.

Some of the studies also identified regional differences that are rather striking. According to Fritsch and Mueller, the effects of start-ups on employment are much more pronounced in the West German agglomerations and in the moderately congested areas than in rural regions. The differences found between West German regions with a relatively high level of labor productivity and low productivity regions are even larger. While the overall effects of start-ups on employment in high-productivity regions are rather positive with the usual s-shaped lag structure, they are negative with a ' $u$ '-shaped lag structure in the low-productivity areas. This clearly suggests that new business formation may, in certain regions, lead to a decrease and not an increase of employment. Negative overall effects of new business formation on employment are also found by Mueller, van Stel and Storey for Scotland and Wales as well as for those regions of Great Britain, which are characterized by a rather low start-up rate. An overall negative impact was also identified by van Stel and Suddle for the rural regions of the Netherlands. Acs and Mueller compared the effects for MSAs with a relatively high share of rapidly growing companies ('gazelles') with the rest of the regions of their sample and found that start-ups in those gazelle regions produced larger employment effects. This can be regarded as an indication that innovative entry has a relatively strong effect on competition and the emergence of supply-side improvements.

\section{Issues for further research and policy implications}

The empirical analyses reported in this special issue suggest a completely new view on the effects of new business formation on regional development. Accord- ing to this new view, the most important impact of entry is that it spurs competition and market selection. If this competition works according to a survival of the fittest scenario, an increase of productivity will occur. At a given level of output, this increase in productivity should lead to a decline in employment, not to additional jobs. Employment growth may occur due to improved competitiveness of the regional economy that is induced by supply-side effects such as increased efficiency, more rapid structural change, amplified innovation and increased variety. For the emergence of these supply-side effects, it is unimportant if the improvements occur on the side of the newcomers or in the incumbent businesses. It is also not very important that the newcomers survive and grow. New business formation should be regarded as part of the competitive process in which market selection plays a central role. It is no doubt that new businesses introduce a dynamic element into the economy and can make an important contribution to development-but this contribution occurs rather indirectly and the success and growth of the entries themselves makes only a small part of this overall effect.

This new view on the effects of entry on economic development has important implications for policy as well as for further research. One implication for future research is that analyses of the post-entry performance, which were in the center of the empirical research on the effect of new business formation on economic development, are of rather limited relevance. Obviously, focusing on the evolution of the new businesses while neglecting the consequences for the incumbents, for innovation activity as well as for the development of output (quality and quantity) is not an appropriate approach for investigating the issue. For a better understanding of the effects of start-ups on development, the new businesses should be regarded as in integral part of the market process. As markets can have rather different characteristics, the effects of entry may vary considerably according to these market specificities such as minimum efficient size, the stage of the product life cycle, the technological regime etc. While much research has been conducted on the chances of new businesses' survival and growth in different market environments (e.g., Audretsch 1995), little is known about the role of market characteristics for the impact of new businesses on 
the development of the market in terms of productivity, efficiency, adjustment to environmental conditions, innovation and product variety. Because the studies collected in this special issue provide strong indications that it takes up to ten years before the main effects of new business formation on industry performance occur, such an analysis should account for sufficiently long time-lags.

The evidence of pronounced regional differences in the magnitude of the employment effects of new business formation clearly indicates that geography is important and that regional conditions can play a rather significant role. Regions differ not only in regard to their level of new business formation activity but also in regard to their ability to transform the impulses of entry into growth. There are also differences between countries and regions with regard to the length of relevant time-lags and to the shape of the lag structure. Obviously, the regional conditions are rather significant and one may well distinguish different types of regional growth regimes in this respect (Audretsch and Fritsch 2002; Fritsch 2004; Fritsch and Mueller 2006).

There are several factors that may be responsible for differences of the impact of entry on regional development and that deserve further investigation. First, there may be substantial variation in the quality of the start-ups between regions. It is plausible to assume that innovative entry constitutes a greater challenge for the incumbents and may have a larger impact in the market and the local economy than non-innovative entry. ${ }^{13}$ Second, the quality and the impact of the entry may be shaped by the availability of resources such as venture capital, qualified labor, knowledge spillovers as well as a supportive infrastructure in the region. Third, the regional share of the industry in which the entry occurs may be significant. If new businesses induce

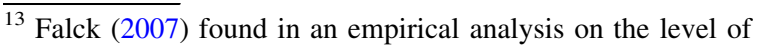
industries in West Germany that short-lived entries, which exit after less than two years, have no significant effect on industry development. A positive effect can, however, be identified for new businesses that remain in the market for a longer period of time. This strongly indicates that the quality of the entries is important for their impact on growth.
}

improvements on the supply-side, a start-up in an industry with a large share of regional employment may have a stronger impact on regional development than a start-up in an industry that has only a small share. ${ }^{14}$ Fourth, differences may exist with regard to the importance of local competition and the spatial diffusion of supply-side improvements. If an industry operates on a global scale, supplyside improvements and an increase of competitiveness are more likely to occur in other regions than in a market that is more or less limited to the region (e.g. personal services). Particularly, the negative effects of entry on regional employment that has been found for certain types of regions casts doubts on policy measures which aim to further regional growth by promoting the emergence of new businesses. We need to know much more about the differences between national and regional growth regimes and their influence on the employment effects of new businesses!

The analyses of effects of new business formation on regional development have an important policy implication in regard to the market mechanism as a selection procedure. If the market does not work according to a survival of the fittest scenario, the competitiveness enhancing supply-side effects will not occur. If the market selection process does not function sufficiently well, entry will be more or less ineffective or even result in a decrease of welfare. Therefore, the highest priority of any policy towards entry is to secure a smooth and reliable selection of the fittest scenario. Particularly, policy should avoid anything that may distort this selection process. In this context, support of entries is a rather critical issue. If incumbent suppliers lose market shares to entries or even have to exit the market because the newcomers gain subsidies, then the selection process does not work properly, and it will not lead to desirable results (c.f. van Stel and Storey 2004). Therefore, any policy that supports new firms after they have been set up may be considered as being questionable. Policy directed at stimulating entry may try to fuel the entrepreneurial spirit, provide advice for nascent entrepreneurs, lower administrative

\footnotetext{
$\overline{14}$ However, in the event of pronounced cross-industry spillovers, the size of the share of the respective industry in the region may not be relevant.
} 
hurdles for start-ups etc.- however, it should abstain from any interference with fair competition. ${ }^{15}$

All in all, the contributions to this special issue provide new insights in an important field. Thus, they also provide important directions for further research that will hopefully lead to further progress.

Acknowledgment I am indebted to Florian Noseleit, Alexandra Schroeter and Roy Thurik for their helpful comments and suggestions on earlier versions of this contribution.

\section{References}

Acs, Z. J., \& Armington, C. (2002). The determinants of regional variation in new firm formation. Regional Studies, 36, 33-45.

Acs, Z. J., \& Armington, C. (2006). Entrepreneurship, geography and American economic growth. Cambridge: Cambridge University Press.

Acs, Z. J., \& Audretch, D. B. (1990). Innovation and small firms. Cambridge: Cambridge University Press.

Acs, Z. J. \& Mueller, P. (2007). Employment effects of business dynamics: Mice, Gazelles and Elephants. Small Business Economics (this issue), doi: 10.1007/s11187007-9052-3.

Arauzo-Carod, J.-M., Liviano-Solis, D., \& Martin-Bofarull, M. (2007). New business formation and employment growth: some evidence for the Spanish manufacturing industry. Small Business Economics (this issue), doi: 10.1007/ s11187-007-9051-4.

Ashcroft, B., \& Love J. H. (1996). Firm births and employment change in the British Counties: 1981-1989. Papers in Regional. Science, 25, 483-500.

Audretsch, D. B. (1995). Innovation and industry evolution. Cambridge: MIT Press.

Audretsch, D. B., \& Fritsch, M. (1994). On the measurement of entry rates. Empirica, 21, 105-113.

Audretsch, D. B., \& Fritsch, M. (1996). Creative destruction: Tubulence and economic growth. In E. Helmstädter \& M. Perlman (Eds.), Behavioral norms, technological progress, and economic dynamics: Studies in Schumpeterian economics (pp. 137-150). Ann Arbor: University of Michigan Press.

Audretsch, D. B., \& Fritsch, M. (2002). Growth regimes over time and space. Regional Studies, 36, 113-124.

\footnotetext{
${ }^{15}$ A critical issue, in this respect, is new high-technology firms. In a number of countries, high-tech start-ups obtain massive public support in terms of soft loans, guarantees for private equity or direct subsidies. One may, however, argue that the support of high-technology start-ups is primarily a means for stimulating the conversion of knowledge into innovative products that would not occur otherwise. But such a policy should not neglect the possible distortion of the market selection process.
}

Audretsch, D. B., \& Keilbach, M. (2004). Entrepreneurship capital and economic performance. Regional Studies, 38, 949-959.

Audretsch, D. B., Keilbach, M., \& Lehmann, E. (2006). Entrepreneurship and economic growth. Oxford: Oxford University Press.

Baldwin, J. R. (1995). The dynamics of industrial competition: A North American perspective. Cambridge: Cambridge University Press.

Baptista, R., Escária, V., \& Madrugo, P. (2007). Entrepreneurship, regional development and job creation: the case of Portugal. Small Business Economics (this issue), doi: 10.1007/s11187-007-9055-0.

Bartelsman, E. J., \& Doms, M. (2000). Understanding productivity: Lessons from longitudinal microdata. Journal of Economic Literature, 38, 569-594.

Baumol, W. J. (2004). Entrepreneurial enterprises, large established firms and other components of the free-market growth-machine. Small Business Economics, 23, 9-21.

Baumol, W. J., Panzar, J. C, \& Willig, R. D. (1988). Contestable markets and the theory of industry structure, revised edition. San Diego: Harcourt Brace Jovanovich.

Birch, D. L. (1979). The job generation process. Cambridge (Mass.): MIT Program on Neighborhood and Regional Change (mimeo).

Birch, D. L. (1981). Who creates jobs? The Public Interest, $3-$ 14.

Birch, D. L. (1987). Job creation in America: How our smallest companies put the most people to work. New York: The Free Press.

Boeri, T., \& Cramer, U. (1992). Employment growth, incumbents and entrants - Evidence from Germany. International Journal of Industrial Organization, 10, 545-565.

Bosma, N., Stam, E., \& Schutjens, V. (2006). Creative destruction and regional competitiveness, EIM Scales Paper H200624, Zoetermeer. Netherlands: EIM Small Business Research and Consultancy.

Braunerhjelm, P., \& Borgman, B. (2004). Geographical concentration, entrepreneurship, and regional growth - Evidence from regional data in Sweden 1975-1999. Regional Studies, 38, 929-947.

Brezinski, H., \& Fritsch, M. (Eds.) (1996). The economic impact of new firms in post-socialist Countries - Bottom up transformation in Eastern Europe. Cheltenham: Edward Elgar Publishers.

Brixy, U. (1999). Die Rolle von Betriebsgründungen für die Arbeitsplatzdynamik. Nuremberg: Bundesanstalt für Arbeit.

Brixy, U., \& Grotz, R. (2004). Entry-rates, the share of surviving businesses and employment growth: Differences between Western and Eastern Germany since unification. In M. Dowling, J. Schmude, \& Dodo zu KnyphausenAufsess (Eds.), Advances in interdisciplinary European entrepreneurship research (pp. 143-152).

Carree, M. A., \& Thurik, A. R. (1999). Carrying capacity and entry and exit flows in retailing. International Journal of Industrial Organization, 17, 985-1007.

Carree, M. A., \& Thurik, A. R. (2003). The impact of entrepreneurship on economic growth. In J. A. Zoltan \& D. B. Audretsch (Eds.), Handbook of entrepreneurship research (pp. 437-471). Boston: Kluwer. 
Carree, M. A., \& Thurik, A. R. (2006). The lag structure of the impact of business ownership on economic performance in OECD Countries. Small Business Economics (this issue), doi: 10.1007/s11187-006-9007-0.

Cooper, A., \& Dunkelberg, W. C. (1987). Entrepreneurial research: Old questions, new answers and methodological issues. American Journal of Small Business, 11, 11-23.

Disney, R., Haskel, J., \&Heden Y. (2003). Entry, exit and establishment survival in UK manufacturing. Journal of Industrial Economics, 51, 91-112.

EIM (1994). Kleinschalig ondernemen 1994, deel II: Regionaleconomische dynamiek en werkgelegenheidscreatie. Zoetermeer: EIM Small Business Research and Consultancy.

Falck, O. (2007). Mayflies and long-distance runners: The effects of new business formation on industry growth. Applied Economic Letters, 14 (forthcoming).

Farinas, J. C., \& Ruano, S. (2005). Firm productivity, heterogeneity, sunk costs and market selection. International Journal of Industrial Organization, 23, 505-534.

Foster, L., Haltiwanger, J., \& Krizan, C. J. (2001). Aggregate productivity growth : Lessons from microeconomic evidence. In: C. R. Hulton, E. R. Dean, \& M. J. Harper (Eds.), New developments in productivity analysis (pp. 303-363). Chicago: University of Chicago Press.

Fritsch, M. (1996). Turbulence and growth in West-Germany: A comparison of evidence by regions and industries. $R e$ view of Industrial Organization, 11, 231-251.

Fritsch, M. (1997). New firms and regional employment change. Small Business Economics, 9, 437-448.

Fritsch, M. (2004). Entrepreneurship, entry and performance of new businesses compared in two growth regimes: East and West Germany. Journal of Evolutionary Economics, $14,525-542$.

Fritsch, M., \& Mueller, P. (2004). The effects of new business formation on regional development over time. Regional Studies, 38, 961-975.

Fritsch, M., \& Mueller, P. (2006). The evolution of regional entrepreneurship and growth regimes. In M. Fritsch \& J. Schmude (Eds.), Entrepreneurship in the region (pp. 225244). New York: Springer.

Fritsch, M., \& Mueller P. (2007). The effect of new business formation on regional development over time: The case of Germany. Small Business Economics (this issue), doi: 10.1007/s11187-9067-9.

Fritsch, M., \& Slavtchev, V. (2007). What determines the efficiency of regional innovation systems? FriedrichSchiller-University Jena. Germany: Jena Economic Research Papers 006-2007.

Fritsch, M., \& Weyh, A. (2006). How large are the direct employment effects of new businesses? - An empirical investigation. Small Business Economics, 27, 245-260.

Geroski, P. (1995). What do we know about entry? International Journal of Industrial Organization, 13, 421-440.

Greene, W. (2003). Econometric analysis (5th ed.). Upper Saddle River. NJ: Prentice Hall.

Gudgin, G. (1978). Industrial location processes and regional employment growth. Westmead: Saxon House.
Gujarati, D. N. (2003). Basic econometrics (4th ed.). Boston: MacGraw-Hill.

Klepper, S. (1996). Entry, exit, growth, and innovation over the product life cycle. American Economic Review, 86, 562583.

Klepper, S., \& Sleeper, S. D. (2005). Entry by spinoffs. Management Science, 51, 1291-1306.

Marshall, A. (1920). Principles of economics (8th ed.). London: Macmillan.

Mueller, P., van Stel, A., \& Storey, D. J. (2007). The effect of new firm formation on regional development over time: The case of Great Britain. Small Business Economics (this issue), doi: 10.1007/s11187-007-9056-z.

Mueller, E., \& Morgan, J. N. (1962). Location decisions of manufacturers. American Economic Review, 52, 204-217.

OECD (2003). The sources of economic growth in OECD Countries. Paris: OECD.

O. Pfirrmann \& G. H. Walter (Eds.) (2002). Small firms and entrepreneurship in Central and Eastern Europe - A socio-economic perspective. Heidelberg: Physica.

Reynolds, P. D. (1994). Autonomous firm dynamics and economic growth in the United States, 1986-90. Regional Studies, 27, 429-442.

Reynolds, P. D. (1999). Creative destruction: Source or symptom of economic growth? In J. A. Zoltan, B. Carlsson, \& C. Karlsson (Eds.), Entrepreneurship, small and medium-sized enterprises and the macroeconomy (pp. 97136). Cambridge: Cambridge University Press.

Reynolds, P. D., et al. (2005). Global entrepreneurship monitor: Data collection design and implementation 19982003. Small Business Economics, 24, 205-231.

Schumpeter, J. A. (1911/1934). Die Theorie wirtschaftlicher Entwicklung, Berlin 1911: Duncker \& Humblot; english edition: The Theory of Economic Development. Cambridge, MA 1934: Cambridge University Press.

Schumpeter, J. A. (1942). Capitalism, socialism and democracy. New York: Harper and Row.

Storey, D. J. (1994). Understanding the small business sector. London: Routledge.

Van Stel, A., Carree, M., \& Thurik, R. (2005). The effect of entrepreneurial activity on national economic growth. Small Business Economics, 24, 311-321.

Van Stel, A., \& Storey, D. (2004). The link between firm births and job creation: Is there a Upas tree effect? Regional Studies, 38, 893-909.

Van Stel, A., \& Suddle, K. (2007). The impact of new firm formation on regional development in the Netherlands. Small Business Economics (this issue), doi: 10.1007/ s11187-007-9054-1.

Verhoeven, W. H. J. (2004). Firm dynamics and labor productivity. In G. Gelauff, L. Klomp, S. Raes, \& T. Roelandt (Eds.), Fostering productivity - Patterns, determinants and policy implications. Amsterdam: Elsevier.

Wong, P. K., Ho, Y. P., \& Autio, E. (2005). Entrepreneurship, innovation and economic growth: Evidence from GEM data. Small Business Economics, 24, 335-350. 